\title{
Carcass characteristics of male and female Japanese quails at 6 weeks of age
}

\author{
SASMITA PANDA ${ }^{1}$, LAXMAN KUMAR BABU ${ }^{1}$, ARUN KUMAR PANDA ${ }^{2}$, KULDEEP KUMAR \\ PANIGRAHY ${ }^{3}$, PROMILA MARNDI ${ }^{4}$ AND SHAILESH KUMAR GUPTA ${ }^{3}$ \\ ${ }^{1}$ Department of Livestock Production and Management, College of Veterinary Science and Animal Husbandry, \\ Orissa University of Agriculture and Technology, BHUBANESWAR (ODISHA) INDIA \\ ${ }^{2}$ ICAR- Central Institute for Women in Agriculture, BHUBANESWAR (ODISHA) INDIA \\ ${ }^{3}$ Division of Livestock Production and Management, National Dairy Research Institute, KARNAL (HARYANA) \\ INDIA \\ ${ }^{4}$ Department of Floriculture and Landscaping, College of Agriculture, Orissa University of Agriculture and \\ Technology, BHUBANESWAR (ODISHA) INDIA \\ Email : smileysas555@gmail.com
}

Article Info : Received : 03.08.2016; Accepted : 30.09.2016

The objective of this study was to evaluate the carcass characteristics of male and female Japanese quails at 6 weeks of age. A total of 100 one-day old Japanese quail chicks were procured and placed in two separate pens each containing 50 chicks. Sex determination was carried out in day-old chicks by cloacal method. All the birds were provided with a balanced diet containing $2900 \mathrm{kcal}$ of ME$/ \mathrm{kg}$ of ration and 24 per cent CP with ad lib provision of water during the entire experimental period. At the end of the experiment, five birds from each group were sacrificed by cervical dislocation and different parameters like eviscerated yield, neck yield, wing yield, back yield, breast yield, giblet yield, thigh yield and drumstick yield were studied. A significantly higher $(\mathrm{P}<0.05)$ percentage of eviscerated yield, giblet yield and breast yield was observed in case of the female Japanese quails as compared to males; however, no significant difference was noticed in terms of neck yield, wings yield, back yield, thigh yield and drumsticks yield among both male and female Japanese quails.

Key words : Male, Female Japanese quail, Carcass characters

How to cite this paper : Panda, Sasmita, Babu, Laxman Kumar, Panda, Arun Kumar, Panigrahy, Kuldeep Kumar, Marndi, Promila and Gupta, Shailesh Kumar(2016). Carcass characteristics of male and female Japanese quails at 6 weeks of age. Asian J. Bio. Sci., 11 (2) : $326-328$. DOI : 10.15740/HAS/AJBS/11.2/326-328. 